\title{
Armed On-board Protection of Danish Vessels Authorisation and Use of Force in Self-defence in a Legal Perspective
}

\author{
Christian Frier*
}

\begin{abstract}
This article examines the legal issues pertaining to the use of civilian armed guards on board Danish-flagged ships for protection against piracy. The Danish model of regulation is interesting for several reasons. Firstly, the Danish Government was among the first European flag States to allow and formalise their use in a commercial setting. Secondly, the distribution of assignments between public authorities and private actors stands out as very pragmatic, as ship owners and contracting private security companies are empowered with competences which are traditionally considered as public administrative powers. Thirdly, the lex specialis framework governing the authorisation and use of force in selfdefence is non-exhaustive, thus referring to lex generalis regulation, which does not take the special circumstances surrounding the use of armed guards into consideration. As a derived effect the private actors involved rely heavily on soft law and industry self-regulation instrument to complement the international and national legal framework.
\end{abstract}

Keywords: Piracy, Private security companies (PSC), Privately contracted armed security personnel (PCASP), Use of force, Denmark

\section{Introduction}

Danish ships and foreign-flagged ships controlled by Danish-based ship owners ${ }^{1}$ are represented in statistics as victims of what is commonly referred to as modern piracy. $^{2}$ Pirate attacks in the waters off the coast of Somalia constitutes a continuous threat to one of the most vital trading areas, as the Gulf of Aden serves as the passage to the Suez Canal, which ties together the

* Christian Frier is research assistant at the Department of Law, University of Southern Denmark. He obtained his PhD in Law in March 2019.

1. The trade and employer organisation 'Danish Shipping' represents around ninety ship owners and offshore companies. An estimated twenty ship owners operate ships under Danish flag, and the same number of ship owners operate ships under foreign flags, available at: https://www.danishshipping.dk/en/om-os/ (last visited 2 January 2019).

2. D. Guilfoyle, Modern Piracy: Legal Challenges and Responses (2013), x. See for other phrasing with similar meaning 'contemporary piracy'; see also A. Petrig, 'Piracy', in D. Rothwell, A.O. Elferink, K. Scott and T. Stephens (eds.), The Oxford Handbook of the Law of the Sea (2015) 843.
Red Sea with the Mediterranean Sea. This pivotal trading route is often navigated by commercial ships flying the Danish flag. When Somali-based piracy peaked in 2011, the number of Danish ships passing the canal represented the seventh largest total, and only surpassed by the Maltese and the British fleet when non-European States are overlooked. ${ }^{3}$ Keeping in mind that the transit ratio does not provide a full-scale picture of the number of Danish ships engaged in commercial activities in the adjacent waters, it does indicate the minimum number of ships exposed to Somali-based piracy. ${ }^{4}$ As a result of such presence, several hijacking attempts and successful kidnappings involving Danish ships have taken place in the past decade. Starting with the hijacking of DANICA WHITE in $2007,{ }^{5}$ this incident was special because the coaster kept a safe distance of 200 nautical miles to the Somalian shore, which at that time complied to international safety recommendations. ${ }^{6}$ Other noteworthy hijackings involved the tugboat SVITZER KORSAKOV and the Bahamas-flagged, but Danish-operated, freighter CEC FUTURE in 2008. ${ }^{7}$ In all these cases, the seafarers were held captive on board their respective vessels for a period between forty-six and eighty-three days before being released against ransom payments. The most notable incident followed in the beginning of 2011 with the hijacking of the Danish coaster LEOPARD. ${ }^{8}$ The crew, two Danes and four Filipinos, was held captive on Somalian ground for 838 days before the seafarers were released against ransom payment in 2013. This hijacking incident was subject to extensive media coverage under the slogan 'get our seafarers home'. The

3. Suez Canal Annual Report 2011, Part 1: Ship Traffic, Table 15. All annual reports can be obtained on www.suezcanal.gov.eg/English/ Pages/default.aspx (last visited 1 February 2019).

4. Around seventy Danish ships are at Any Given Time Navigating in Piracy-prone Waters, available at: https://www.danishshipping.dk/en/ policy/pirateri/ (last visited 1 February 2019).

5. 'DANICA WHITE - Piratoverfald og kapring den 1. juni 2007' (Danish text), Danish Maritime Authority Investigation, November 2007.

6. A. Petrig and R. Geiss, Piracy and Armed Robbery at Sea: The Legal Framework for Counter-piracy Operations in Somalia and the Gulf of Aden (2011) 10, note 46.

7. The incident was subject to Danish criminal jurisdiction, because the kidnappers contacted the Danish branch to negotiate ransom payment; see B. Feldtmann, 'Er strafferet et effektivt middel i kampen mod sørøveri?', in Liber Amicarum et Amicorum Karin Cornlis (2010) 113-117.

8. Danish Maritime Accident Investigation Board Report: 'Piratoverfald d. 12. januar 2011' (Danish text) can be obtained on http:// www.dmaib.dk/Sider/Forside.aspx (last visited 1 February 2019). 
combined ransom payments in the mentioned cases amounted to a staggering 8 million euros and impelled both criminal investigations and civil lawsuits. ${ }^{9}$ Through that prism, Somali-based piracy has a direct impact on Danish interests' in the broadest sense. As a result, counter-piracy responses were swiftly considered a key policy issue as stipulated by the Danish Government in the first 'Strategy for the Danish Counter-Piracy Effort' dating back from 2011. ${ }^{10}$

\subsection{The 'Three Pillars' of the Strategy}

The governments' reaction towards piracy has been holistic and encompasses all three 'pillars' as described by Feldtmann in her contribution to this special issue. Danish warships have been deployed in coalition forces, including, but not limited to, Operation Ocean Shield and the EU Operation ATALANTA. ${ }^{11}$ The presence of warships brought some stability to the region in the form of the International Recommended Transit Corridor (IRTC). But efforts also revealed shortcomings, as pirates started to expand their operation area by using so-called mother ships, which are able to carry smaller skiffs and equipment on much longer distances. ${ }^{12}$ In addition to this development, law enforcement operations led to frustration due to so-called catch and release-strategies and unsuccessful attempts to prosecute alleged pirates in Danish courts. Moreover, the Prosecution Service was criticised by the Danish High Court for neglecting constitutional rights of individuals retained on a Danish warship ${ }^{13}$ as well as scholarly criticism for completing an extradition of individuals to the Seychelles. Also, the government's attention has been directed to diplomacy and regional capacity building to address the root courses of piracy. ${ }^{14}$ Among the drivers is the non-functional government of Somalia with the subsequent lack of stewardship and effective control of own territorial waters. Other factors include dumping and illegal fishing, which have a negative impact on fish

9. U2011.354 $\varnothing$ (Danish case law) in which the High Court in a civil lawsuit ruled against the crew members of DANICA WHITE. The judges argued on the merits of the case, especially that the ship owner was not negligent.

10. 'Strategy for the Danish Counter-Piracy Effort 2011-2014', Ministry of Foreign Affairs of Denmark, May 2011 (hereafter antipiracy strategy 2011); replaced by the 'Strategy for the Danish Measures against Piracy and Armed Robbery at Sea 2015-2018', Ministry of Foreign Affairs of Denmark, March 2015 (hereafter antipiracy strategy 2015); and currently in force the 'Priority Paper for the Danish Efforts to Combat Piracy and Other Types of Maritime Crime 2019-2022', Ministry of Foreign Affairs of Denmark, November 2018 (hereafter antipiracy strategy 2019).

11. B. Feldtmann, 'Jura som led i dansk aktivistisk udenrigspolitik til søs', 90(1) Økonomi og Politik 11-23 (2017).

12. Best Management Practices to Deter Piracy and Enhance Maritime Security in the Red Sea, Gulf of Aden, Indian Ocean and Arabian Sea (hereinafter BMP5); see also A. Petrig, 'The Use of Force and Firearms by Private Maritime Security Companies against Suspected Pirates', 62(3) ICLQ 668 (2013).

13. U 2014.1044 Ø (Danish case law)

14. M.D. Evans and S. Galani, 'Piracy and the Development of International Law', in P. Koutrakos and A. Skordas (eds.), The Law and Practice of Piracy at Sea (2015) 362. stocks and marine environment, ${ }^{15}$ ultimately 'pushing' local fishermen to pursue other sources of income. These underlying issues, whether acting alone or in concert, have led the Danish Government to support long-haul initiatives to eradicate Somali-based piracy. ${ }^{16}$ Nevertheless, such efforts provide no immediate comfort against pirates on the lurk for venerable commercial ships and on that background the way was paved for the controversial policy of allowing Privately Contracted Armed Security Personnel (PCASP) on board Danishflagged ships. At the time of writing, the Danish naval fleet is no longer active in counter-piracy operations and no individuals have been prosecuted for the act of piracy in Danish courtrooms.

When discussions for additional security measures first took off in 2008, the initial call from the shipping industry focused on the use of 'state agents' in the form of marine or military personnel, commonly referred as vessel protection detachment personnel teams (VPD teams). ${ }^{17}$ The industry's line of argumentation followed from the concept of state protection, theoretically captured in the doctrine of 'monopoly of force', despite not voicing the notion itself. VPD teams had previously been deployed on commercial ships for transportation of military equipment to the Danish troops' campaign in Afghanistan, and on board ships carrying supplies to Somalia on behalf of the UN World Food Programme. ${ }^{18}$ These deployments were nevertheless considered as exceptions, and it was clear from the very beginning that the government did not intend to formalise the arrangement, as the request was swiftly turned down. The reasoning, according to the Minister of Defence, was that it would create an undesirable precedent if Danish soldiers were to provide protection for Danish ships rather than take part in international coalitions to the greater benefit of the international commercial fleet. Furthermore, the use of such personnel was not assessed to be a costeffective use of sparse military resources. ${ }^{19}$ Based on that argumentation, the use of private security companies (PSCs) and ultimately PCASP teams in a commercial setting was pursued as the alternative solution. Accordingly, a dire need for national and international legal instruments emerged to define authorisation criteria, set standards for the application of PCASP teams and ensure control in the form of oversight mechanisms. It is especially distinct within the field of shipping because of the structural compliance deficit following from the great distance between Danish authorities and piracy-prone waters, where it can become relevant to deploy armed guards. 


\subsection{Overview of the Regulatory Framework}

According to the flag State principle as defined in the United Nations Convention on the Law of the Sea, ${ }^{20}$ ships are subject to the nationality of the state whose flag they are entitled to fly. ${ }^{21}$ This includes the obligation to 'effectively exercise its jurisdiction and control in administrative, technical and social matters over ships flying its flag'. ${ }^{22}$ The exclusive jurisdiction bestowed upon flag States grants primary prescriptive competence and enforcement powers. For many good reasons, however, the overall regulation of shipping follows from the international and regional levels. ${ }^{23}$ Shipping is one of the most global industries, which is fortified by the profound number of marine and maritime-specific treaties governing the sector. ${ }^{24}$ Denmark holds a long-standing tradition of submission when it comes to ratifying regional and international agreements. As most treaties were drafted in a time when piracy was considered as a historical phenomenon, ${ }^{25}$ these instruments do not entail much regulation regarding piracy and especially the use of armed guards. ${ }^{26}$ As articulated in 2011 by the UN's specialised agency, the International Maritime Organization (IMO), the absence of applicable regulation and industry self-regulation coupled with complex legal requirements gives cause for concern. ${ }^{27}$ Accordingly, the legal framework is generally described as complex and in a state of flux. ${ }^{28}$ To mend the lacunas in international law, a body of what is commonly referred to as soft law and industry self-regulation (ISR) has emerged to supplement flag State rules. It includes, inter alia, the four IMO interim guidances drafted by the Maritime Security Committee (MSC) ${ }^{29}$ and the

20. The 1982 United Nation Convention on the Law of the Sea (hereinafter the UNCLOS).

21. UNCLOS Art. 91.

22. UNCLOS Art. 94, Subsection 1

23. K.M. Siig, 'Private Classification Societies Acting on Behalf of the Regulatory Authorities within the Shipping Industry', 482 SIMPLY 220 (2016)

24. Available at: http://www.imo.org/en/About/Conventions/ListOfCon ventions/Pages/Default.aspx (last visited 1 February 2019)

25. Petrig, above n. 2, 843.

26. UNCLOS Arts. $100-07$ and 110 focusing on state's rights and obligations pertaining to the repression of piracy.

27. IMO Maritime Safety Committee (MSC), 'Revised Interim Guidance to Private Maritime Security Companies Providing Privately Contracted Armed Security Personnel On Board Ships in the High Risk Area' (25 May 2012) MSC.1/Circ.1443, Annex (1).

28. Petrig, above n. 12, 668

29. MSC.1/Circ.1443; IMO Maritime Safety Committee, 'Revised Interim Recommendations for Flag States regarding the Use of Privately Contracted Armed Security Personnel On Board Ships in the High Risk Area' (12 June 2015) MSC.1/Circ.1406/Rev.3; IMO Maritime Safety Committee, 'Interim Recommendations for Port and Coastal States regarding the Use of Privately Contracted Armed Security Personnel On Board Ships in the High Risk Area' (16 September 2011) MSC.1/Circ.1408; IMO Maritime Safety Committee, 'Revised Interim Recommendations for Port and Coastal States regarding the Use of Privately Contracted Armed Security Personnel On Board Ships in the High Risk Area' (25 May 2012) MSC.1/Circ.1408/Rev.1; IMO Maritime Safety Committee, 'Revised Interim Guidance to Shipowners, Ship Operators and Shipmasters on the Use of Privately Contracted Armed Security Personnel On Board Ships in the High Risk Area' (25 May 2012) MSC.1/Circ. 1405/Rev.2. industry's Best Management Practices ${ }^{30}$ as the most prominent examples. Other instruments that have gained momentum include the world's leading shipping association BIMCO's standard contract, Guardcon, for the employment of security guards on vessels. ${ }^{31}$ The ambit of Guardcon is to govern the contractual relationship between the ship owner and the PSC; however, Guardcon also affects areas of public law. Most notably, the contract seeks to govern the relationship between the master of the ship and the PCASP team, which is basically a question of maritime law and criminal law. ${ }^{32}$ Another entity of relevance is the International Organization for Standardization (ISO). ISO has promoted a standard for PSC accreditation. ${ }^{33}$ This standard is voluntary unless made mandatory in national law or according to a de facto requirement articulated by ship owners themselves or other relevant stakeholders, for example, cargo owners and insurance companies. ${ }^{34}$ Both BIMCO and ISO's status in shipping 'governance' is fortified by their consultative status to IMO. In addition to these international legal instruments, Danish stakeholders have issued a guideline in which compliance to international guidelines and standards is emphasised. ${ }^{35}$ Though it makes sense - at least from a more practical perspective to involve private actors in law-making initiatives - it also underpins the regulatory uncertainty, as the interaction between traditional state-based sources of law and ISR is immensely complex.

A follow-up question triggered by the mosaic of different sources of law pertains to administrative and criminal sanctions. This is especially relevant from a Danish perspective, as the transition from a state-controlled regime to delegation of authority to private actors basically means that the ship owner or the contracting PSC becomes responsible for actions which affect the authorisation and the actual deterrence act at sea. Obligations that are traditionally considered as administrative tasks performed by governmental institutions and state agents only. Such degree of flexibility comes with a price in the form of potential criminal liability. Accordingly, formal sanctions can be imposed in case of any violations, for example, if the vetting of the guards does not meet the requirements or the permit has expired. This is not less

30. Best Management Practice to Deter Piracy and Enhance Maritime Security in the Red Sea, Gulf of Aden, Indian Ocean and Arabian Sea (June 2018; hereinafter BMP5) replacing Best Management Practice for Protection against Somalia-Based Piracy (August 2011; hereinafter BMP4).

31. Baltic and International Maritime Council's standard contract for the employment of security guards on vessels (Guardcon). A copy of Guardcon can be obtained from BIMCO's webpage https:// www.bimco.org/

32. Guardcon, Part II, cl. 8.

33. ISO 28007-1:2015 Ships and Marine Technology - Guidelines for Private Maritime Security Companies (PMSC) Providing Privately Contracted Armed Security Personnel (PCASP) On Board Ships (and Pro Forma Contract) - Part 1: General (ISO 28007).

34. Protection and indemnity insurance ( $P \& I$ insurance) are immensely important to the ship owners, as any loss of insurance can have detrimental implications.

35. Guidelines for navigation waters with a piracy threat, including the use of private armed guards, no. 3/2014. Available at: https:// www.danishshipping.dk/politik/pirateri/ (last visited 1 February 2019). 
relevant to the potential use of force in self-defence. From a normative perspective, less is often required to impose administrative penalties, such as when it comes to withdrawing an existing license. From a criminal law perspective, however, the fundamental principles of legality and lex certa may constitute a curtailment on applying various soft laws and ISR instruments as a legal basis.

\subsection{Objective and Content}

The purpose of this article is to examine and evaluate the current state of law for the use of PCASP on Danish ships, by focusing on the authorisation scheme and the use of force in self-defence, respectively. On the background of these thematic cornerstones it is argued throughout this contribution that the Danish form of regulation can be characterised by a high degree of involvement from private actors. This statement is supported by the level of delegation of authority admitted to private actors as well as the fact that the legal framework relies on the interplay between formal and informal sources of law. The latter category covers soft law and ISR instruments which are fully or in part formulated by private actors. This interrelationship is a wellknown feature in shipping regulation, but when it comes to gun regulation and the use thereof, it is unprecedented in Danish law. From a methodological perspective some distinct challenges can therefore be identified when analysing the use of private armed guards from a Danish flag State perspective. First, attention is devoted to the interplay between the various sources of law and to what degree the soft law and ISR instruments are binding. Second, taking the sparse specific national regulation into consideration, the question of interpretation arises. The article is structured in four parts. Section 2 focuses on the authorisation. It outlines the background and development towards the current dual licensing, comprising the individual license and the general license, respectively. ${ }^{36}$ On that background the analysis is conducted. Section 3 concerns the protection against piracy with a special emphasis on how to operationalise the use of force in self-defence as well as the interaction between the master of the ship and the PCASP team. The examination is concluded in Section 4 with some general remarks reflecting on the nexus between the need for flexibility and fundamental principles of state control. Finally, an outlook for the future of the Danish form of regulation and some de lege ferenda proposals are articulated.

\section{Authorisation}

From the time it was decided to allow PCASPs on board Danish ships, the process of formalising an authorisation scheme commenced. In that process, two regulatory

36. The notions 'individual license' and 'general license' are not terminologically defined in Danish law, but the terms are commonly used by the Ministry of Justice and accordingly applied in this article. barriers needed to be addressed. ${ }^{37}$ One is the question of obtaining weapon permits and the other aspect concerns the selection of PSCs and vetting of their personnel. Taking these themes into consideration, both areas of law are subject to fundamental principles, including but not limited to state control and oversight mechanisms. ${ }^{38}$ In accordance with the introductory articles of the Weapons Act, ${ }^{39}$ it is illegal to import, manufacture, possess or use firearms and related equipment unless a certificate is obtained beforehand. ${ }^{40}$ Certificates are issued on a strict basis, and a prerequisite for granting a certificate is the applicant's personal behaviour and mental fitness, proving that the person is not considered 'unfit'. Denmark has a very strict gun regulation, thus only allowing firearms for hunting. Likewise, it is a basic requirement for private actors engaging in commercial security-related services, that an authorisation has been granted and that all individuals acting as guards are vetted by the authorities. ${ }^{41}$ Private security guards acting in civil society are not allowed to carry weapons of any kind, nor do such persons have any formal competence to use force. Private security guards are thus bound by, and confined to, the same rules as all individuals when it comes to acting in self-defence and making civil arrests. As a result, no obvious link can be drawn between the Weapons Act and the Private Security Service Act apart from the underlying principles articulated here.

Keeping these regulatory barriers in mind, the Ministry of Justice decided to broaden the scope for issuing weapon permits to allow the so-called individual license. Furthermore, the need for rules on the scope of application, type of ships and maritime safety aspects had to be taken into consideration. As a result, the first individual license for the use of PCASP was granted in March 2011 pursuant to the legislation in force at that time. No amendment was thus required, solving the need for a legal basis. This hands-on ministerial approach was fortified by the government's promise to 'adopt a more open approach to the use of armed civilian guards, so that it will no longer - as it has previously been the case - be necessary to substantiate a specific and extraordinary threat against the ship in question' and the government further committed to maintain a 'close dialogue with the industry in order to make the application process as flexible and un-bureaucratic as possible' ${ }^{42}$ This policy statement underpins the delicate balance between upholding the fundamental principles of state control, within an industry well-known for its structural lack of

37. The Danish model of regulation is heavily inspired by the Norwegian pilot scheme, which was among the first regulatory frameworks with substantive content; see Bill proposal L 116 (2011-2012), 7-8.

38. C. Frier, 'Autorisation af vagtvirksomhed og godkendelse af vagter i dansk ret', in Juridiske emner ved Syddansk Universitet 2015 (2015) 277-278.

39. Weapons Act (LBK no. 1005, 22 October 2012)

40. Weapons Act, Arts. 1 and 2.

41. Private Security Service Act (LBK no. 112, 11 January 2016) Art. 3 and the supplementary Private Security Service Ordinance (BEK no. 1408, 4 December 2017) Art. 5.

42. Antipiracy strategy 2011, 25 
oversight mechanism, and the dire need to accommodate the industry's call for a more flexible authorisation. An individual license is granted on a single basis and is tied to an individual person with a specific weapon for a named ship and a predetermined route. The authorisation is subject to thorough vetting procedures in the form of personal background checks of the potential guards. It also includes information regarding the applied ship protection measures and the intended voyage. The list of information which the ship owners must be adhering to is promulgated on the ministry's webpage. ${ }^{43}$ The examination involves at least two state institutions besides the Ministry of Justice, namely, the Ministry of Defence (routing) and the Danish Maritime Authorities under the auspices of the Ministry of Industry, Business and Financial Affairs (procedure). ${ }^{44}$ Consequently, the individual license largely observes the fundamental principle of administrative control. One important point to note, however, is the case processing, which takes at least two weeks and possibly longer if the application includes persons with foreign nationality. ${ }^{45}$ For practical reasons, this timespan was subject to continuous industry criticism, as the level of flexibility did not match the business model of shipping. ${ }^{46}$ To fully understand the individual license's lack of flexibility and the reason for ship owners becoming more vocal, it is essential to understand some features pertaining to the carriage of goods by sea. There are many ways in which a ship can be utilised in trade, and the decisive factors are related to economic incentives. ${ }^{47}$ A general distinction can be drawn between liner trade and chartering. Liner trade, or carriage of general cargo as referred in international conventions, ${ }^{48}$ is generically defined as transportation of cargo against freight on a predetermined schedule and route. The prefixed conditions ensure that the line operator can foresee the need for rerouting or additional protection depending on the anticipated threat in the given trading area. This is vastly different in chartering. Especially if a ship is fixed on a time charter under which the charterer assumes the commercial control, meaning that the master is bound to perform voyages as per instruction by the charterer, subject to the contract of carriage. Shipping is a financially sensitive business, and it is therefore of utmost importance that ships can be redirected on a short notice, and even shorter than the two weeks expected for granting an individual license. Because the waters

43. Now available on the homepage of the Danish Police see https:// politi.dk/soeg-om-tilladelse/vaaben/civile-bevaebnede-vagter-paadanske-lastskibe (last visited 1 February 2019)

44. See particularly Section 2.1 .

45. P. Cullen, Surveying the Market in Maritime Private Security Services in Maritime Private Security, Market Responses to Piracy, Terrorism and Waterborne Security Risks in the 21st Century (2012) 31-35.

46. J. Berndtsson and Å.G. Østensen, 'The Scandinavian Approach to Private Maritime Security - A Regulatory Façade?', 46 ODIL 144 (2015).

47. T. Falkanger, H.J. Bull and L. Brautaset, Scandinavian Maritime Law (2017), 255-7.

48. The Norwegian Maritime Code, which is the best available translation of the Danish 'Søloven' can be obtained on http://folk.uio.no/erikro/ WWW/NMC.pdf (last visited 1 February 2019). around Africa, particularly the waters off the coast of Somalia, are pivotal to everyday trade, it would constitute a considerable contractual curtailment, if this region was not part of the so-called ordinary 'worldwide trading' clause agreed in many time charter parties. Another point of criticism has been directed at the specific tie to a named guard, meaning that a weapon permit cannot be transferred in case the original holder is prevented, ultimately placing the ship owners between a stone and a hard place, when deciding to honour a contractual promise of transport and taking the seafarer's safety into consideration.

Eventually, the practical shortcoming prompted a legal reform in 2012 with the scope of granting easier access for ship owners to obtain a 'general license'. This policy change reflected the intention of industry dialogue. The Minister of Justice stated in his bill proposal speech that 'the underlying reason for the proposed bill is that the current licensing scheme [the individual license] has proven to be difficult to reconcile to the needs of the shipping industry, which is to the detriments of the safety of the seafarers'. ${ }^{49}$ Consequently, the transition from a state-controlled baseline to delegation of authority to private actors means that the ship owners or contracting PSCs become responsible for different assignments pertaining to the authorisation and vetting process.

The outcome is laid down in Article 4c in the Weapons Act, which stipulates that 'the Minister of Justice..., grants shipping companies a general license to use civilian armed guards aboard cargo ships flying the Danish flag.' According to paragraph 2, 'the Minister of Justice shall lay down terms and conditions for the issuing and use of permits pursuant to subsections 1.' Article $4 \mathrm{c}$ is structured so that the first rule concerns the authority to grant a general license, whereas the second rule addresses the subject matters which the ministry must take into consideration when drafting secondary legislation at the administrative level. This entails: the form and content of an application, requirements for weapons and ammunition types and their storage, keeping a weapon log, the eligibility of the guards, reporting in case of attacks and the validity of the license. ${ }^{50}$ The rules are codified in the ministerial ordinance named the Use of Armed Civilian Guards on Danish Cargo Ships (ACG Ordinance). ${ }^{51}$ As the ACG Ordinance also accompanied the bill proposal, it could be argued that it is rubber-stamped by the parliament's voting.

Ultimately, when a Danish ship owner decides to hire a PSC team for any given voyage, it is possible to apply for an individual or general license. Keeping in mind that the latter was modelled to meet the needs of the shipping industry and reduce administrative bureaucracy, it is fair to assume that it has developed into the preferred solution. According to information obtained

49. See L 116, 'Skriftlig fremsættelse' (28 March 2012). Author's underlining and translation.

50. Weapons Act, Art. 4c(2).

51. BKG no. 698 om brug af civile bevæbnede vagter på danske lastskibe (27 June 2012) 
from a requested access to formal records from the Ministry of Justice, it is indeed the case. To break down the numbers, three cut-off dates should be noted. The first date is March 2011 when the first individual licenses were granted. The second date is June 2012 when the general license came into force, providing ship owners with an alternative solution. Finally, ultimo 2017 when the information was obtained. ${ }^{52}$ During this time span, a total of 158 individual licenses had been issued, but only 17 in the wake of the legal reforms. This indicates the ship owner's preference. With regard to the general license, a total of sixty-nine have been issued within the period. The general license is granted on a one-year basis. When dividing the number of licenses against the six-year time span, it indicates that around ten to twelve shipping companies hold a general license at any given time. ${ }^{53}$ It seems plausible given the number of ship owners with Danish-flagged ships under their command. On that background the following analysis focuses primarily on the form, content and effect of the general license as it has developed into the preferred license.

\subsection{Ship Protection Measures}

It is important to note that the use of PCASP is considered as a supplement and not an alternative to general ship protection measures. A prerequisite for granting a license in the first place is that the ship is sufficiently secured according to vessel type and an overall risk assessment of the intended voyage. The ambit is to ensure that shipping activities are performed in a safe manner, without putting the seafarer's lives at risk or endangering the marine environment. ${ }^{54}$ The special ordinance is the Technical Standard for Precautionary Measures for Piracy and Armed Robbery (Antipiracy Ordinance) administered by the maritime authorities. ${ }^{55}$ The ordinance must be adhered to for all voyages in piracy-prone waters, regardless of the use of PCASP teams. The main obligation bestowed upon the ship owner is to make a procedure as introduced in Section 2 earlier. Procedure in the most simplistic meaning of the word refers to a series of acts in a particular order of succession. In relation to a ship's safety management system, a procedure sets standards of conduct, and the instrument functions as a barrier against unwanted and unsafe activities. ${ }^{56}$ The procedure must, according to Article 6 of the Antipiracy Ordinance, encompass

52. Obtaining this information has proven to be quite laborious because it requires formal consultation from each ship owner. Apparently, this information is considered a 'trade security', which means the Ministry of Justice is reluctant to provide numbers.

53. A license is linked to the document of compliance (DOC). For more information on the DOCs, see Falkanger, Bull and Brautaset, above $\mathrm{n}$. 47, chapter 3. Separate DOCs will usually be issued for each division, e.g. tanker division and container division. Ship-owning companies will potentially have to obtain multiple general licenses.

54. Sea Safety Act (LBKG no. 1629, 17 December 2018) Art. 2 mirroring the principles in the SOLAS Convention.

55. BEK no. 1084, 23 November 2011.

56. Danish Maritime Accident Investigation Board, Safety Report (June 2016), Tilted 'Proceduralizing Marine Safety - Procedures in Accident Causation', 6 instructions on prevention of pirate attacks. This includes, inter alia, a general risk assessment of the intended route, application of appropriate measure for the protection of crew and ship, and training and information sharing. ${ }^{57}$ The ordinance consists partly of substantive rules, such as reporting requirements, and partly of references to other legal instruments. Thus, the Antipiracy Ordinance is an example of national support to international guidelines, which is developed by IMO as well as the industry in the form of Best Management Practices. It is not a formal codification in casu, ${ }^{58}$ but rather a 'rule of reference', meaning that the ship owners must take the various legal instruments into consideration, when preparing the procedure. A supple style of regulation well-known within maritime safety that tolerates changes without the need of amendments in national law. On the other hand, this approach allows rather drastic changes to the underlying guidelines.

In assessing the precautionary measures to be taken on each ship, the risk assessment shall be evaluated on the basis of the ship's characteristics, for example, size, type of cargo, freeboard and speed. This means that the threshold for compliance pertaining to coasters and vessels with cargo stowed below the water surface are generally higher than large container vessels. If the ship is intended to navigate in the defined high-risk area, ${ }^{59}$ the ship owner must also adhere to additional measures, including those listed in BMP. ${ }^{60}$ Accordingly, it can be concluded that IMO guidelines and ISR instruments are mandatory, despite the combination of vague recommendations leave the ship owner with an assessment.

To evaluate procedures a distinct system has evolved in shipping, as compliance control is generally exercised by private classification societies acting on behalf of the maritime authorities. ${ }^{61}$ This is also the case with the Antipiracy Ordinance. ${ }^{62}$ This practice supports the notion of 'privatisation' because it relies on each ship owner's ability to adopt high-standard procedures as well as the recognised organisations control hereof.

\subsection{Scope of Application and Requirements}

The ACG Ordinance is almost only governing the authorisation process itself. Few articles, however, are governing the situation on board the ship. One article details the obligation to keep a weapons $\log$ and another article refers to the duty of reporting in case of an incident that has caused the use of force in self-defence. ${ }^{63}$ These obligations will be discussed more in detail in Section 3.

57. Art. 6, para. 1, no. 1-6.

58. An example of more formal codification of IMO guidelines can be seen in the German model of regulation, see the contribution of Salomon in this special issue.

59. BMP5, 2

60. BMP5 entails a comprehensive list of actions and precautionary measures, such as razor wire, CCTV-monitoring citadels/safe muster points, see BMP5, 11-20.

61. See e.g. T. Falkanger, 'Hans Jacob Bull and Lasse Brautaset', Scandinavian Maritime Law 92 (2017).

62. Antipiracy ordinance, Art. 12.

63. Arts. 6 and 8. 
A general license can be obtained for commercial voyages performed by cargo ships within a geographical area with a risk of pirate attacks or armed robbery. ${ }^{64}$ Passenger ships, fishing vessels and pleasure crafts are instead referred to the individual license. ${ }^{65}$ An application according to Article 3 must include identification of the ship-owning company, including its place of business and relevant contact details. If the ship owner and the ISM responsible are not the same entity, the latter must also support the application. ${ }^{66}$ The applicant shall also confirm that procedures for precautionary measures are developed and circulated among relevant parties, for example, crew members, for familiarisation. ${ }^{67}$ Finally, it is required by the ship owner to state the concrete need for PCASP protection and why the precautionary measures are not adequate to prevent pirate attacks. ${ }^{68}$ The latter requirement appears to be irrelevant, as the general license is not related to one specific voyage, as it is the case with the individual license.

The obligation to present the necessary information is not subject to criminal liability, as any lack of compliance will lead to rejection. The validity of a general license extents to one year, ${ }^{69}$ and during that period it may be utilised as often as the ship owner finds it necessary, of course within the scope of application. Surprisingly, there is no duty to inform Danish authorities prior to the embarkment of PCASP. On that background it can broadly be stated that the lax requirements accommodate the industry's call for flexibility.

\subsection{Regulation of Private Security Companies}

Another issue that must be addressed in detail is the regulation of PSCs which offer services in the Danish market. The regulation of PSCs has become the centre of attention in the international debate, which can be traced to similar discussions on the use of PSCs in warzones and areas of conflict. ${ }^{70}$ The concerns relating to the use of private security providers are generally overlapping, focusing on accountability and liability. ${ }^{71} \mathrm{How}-$ ever, the legal framework governing the two distinct areas is vastly different. Humanitarian law and the laws of war are generally applicable in war and conflict situations, whereas maritime law is applicable at sea. ${ }^{72}$ Accordingly, IMO is thus regarded as a pioneer when it comes to PSC initiatives, essentially suggesting that flag States should have a firm policy and establish an appro-

64. Art. 1, para. 2.

65. Art. 1, para. 1.

66. Art. 3, para. 2, no. 2.

67. Art. 3, para. 2, no. 5 .

68. Art. 3, para. 2, no. 6 .

69. Art. 9.

70. E.g. A. Petrig, 'Looking at the Montreux Document from a Maritime Perspective', 2 Maritime Safety and Security Law Journal (2016).

71. Y.M. Dutton, 'Gunslingers on the High Seas: A Call for Regulation', 24 Duke JCIL 107, at 123-8 (2013); J. Kraska, 'International and Comparative Regulation of Private Maritime Security Companies Employed in Counter-Piracy', in D. Guilfoyle (ed.), Modern Piracy: Legal Challenges and Responses (2013) 222.

72. D. Guilfoyle, 'The Use of Force against Pirates', in M. Weller (ed.), The Oxford Handbook of the Use of Force in International Law (2015) 1063-1064. priate legal framework for the use of PSCs. ${ }^{73}$ Dating back to 2009 and in the following years, the question pertaining to the use of PSCs has been a recurring item on the agenda of IMO. States, industry stakeholders, NGOs and private entities have all taken part in influencing IMO's position and guidelines ${ }^{74}$ with an emphasis on flag State responsibility. Surprisingly, the Danish Government has to a certain point derogated from this point, as PSCs' services performed on ships in international and foreign waters fall outside the scope of the Security Service Act, thus leaving maritime PSCs unregulated. This is clarified by the Ministry of Justice on several occasions because the statute is confined to the Danish territory. ${ }^{75}$ Whether this interpretation can be substantiated or not is subject to some scholarly debate, ${ }^{76}$ but it seems striking that the government refrained from regulating the topic at all. The absence of a PSC-specific regulation might very well be preferable from an economic point of view because Danish ship owners are not confined to what can perhaps develop into a monopolistic or oligopolistic market, with few authorised providers and limited competition. On the other hand, it raises the question of how it can be ensured that PSCs are fit for the task. This is relevant to avoid risking a race to the bottom-push by precluding substandard contractors. Furthermore, it might be difficult for well-established PSCs to demonstrate their qualifications. As an alternative, parties tend to turn to private accreditation.

Most notable is the ISO 28007 standard, ${ }^{77}$ which has gained international momentum as well as support from IMO itself. ${ }^{78}$ Standards as a tool of control and harmonisation hold a pivotal position in shipping in general. ${ }^{79}$ In that context, standards are instruments which define criteria for the purpose of reaching an ideal, prearranged model or outcome. Thus, it makes good sense to take advantages of the organisational structure already in place in ISO. However, standards do not create legal obligations just by the mere fact of their existence, and their 'binding effect' is based on voluntary support, unless induced by a public legal norm. ${ }^{80}$ The current state of Danish law does not induce a de jure obligation

73. IMO, MSC.1/Circ.1443, annex.

74. J. Kraska, 'International and Comparative Regulation of Private Maritime Security Companies Employed in Counter-piracy', Modern Piracy: Legal Challenges and Responses 224 (2013).

75. Bill Proposal (L116 2011-2012), Q\&A, S 1084 dated 7 December 2011.

76. Frier, above n. 38, 278-9.

77. Originally issued as a PAS (Publicly Available Specification); see IMO MSC 91/17/1 (21 September 2012), ISO PAS 28007 Ships and marine technology - Guidelines for Private Maritime Security Companies (PMSC) providing privately contracted armed security personnel (PCASP) on boar ships (and pro forma contract - Part 1, submitted by ISO.

78. IMO MSC.1/Circ.1443, annex

79. C.N. Murphy and J. Yates, The International Organization for Standardization: Global Governance through Voluntary Consensus (2009) 50-51; S. Wood, The International Organization for Standardization, Business Regulation and Non-State Actors - Whose standards? Whose Development? (2012) 82.

80. M.A. Carreira da Cruz, 'Regulating Private Maritime Security Companies by Standards: Causes and Legal Consequences', 3 Maritime Safety and Security Law Journal 66 (2017). 
to comply to the standard, though it appears that a de facto demand from industry stakeholders has promoted the use of ISO 28007. The standard is thus supported in the Danish guideline. ${ }^{81}$ Nevertheless, this assumption does not fully safeguard against careless ship owners.

The standard itself is directed to PSCs as the principal addressee. Consequently, it is bestowed upon every security provider to demonstrate ISO compliance. It intends to delineate a comprehensive set of requirements to which a PSC must abide. This includes, inter alia, legal, financial, management and risk perspectives within its own internal organisation. It also adds external relationships to the list, including national authorities, ship owners, insurance companies and subcontractors. The standard is divided into six separate parts; Parts 4 to 6 detail the normative content. Regarding the question of authorisation, Section 4 concerning security management system elements for PSCs stands out. It serves as the basis of the standard and stipulates in subsections what is expected from PSCs to comply with the standard. For obvious reasons the standard exceeds the non-existing demands in Danish law, but it also goes further than the requirements listed in the Service Security Act for PSCs operating at land. In summary, it is fair to consider the standard as a wide-ranging due diligence examination that aims to raise the bar significantly.

\subsection{Eligibility of the Guards}

One of the most delicate topics concerns the eligibility of the guards. According to Article 7 of the ACG Ordinance, the ship-owning company must either undertake to vet the guards or ensure that the contracting PSC can provide documentation on adequate procedures. Given the nature of shipping and the distribution of tasks, it is fair to assume that the latter option is exercised on a general basis. This represents a more extreme example of delegation of authority between private actors, which is most unusual in a Danish context. In the following section, the requirements under Danish law are examined. On that background it is evaluated if these requirements are higher or lower than international standards.

To be considered eligible under Danish law, six criteria shall be fulfilled, ${ }^{82}$ including identification, age of at least twenty years and submission of criminal records. These criteria are straightforward and do not presuppose any subjective assessment. The more critical criteria include: (i) that the person has not been charged with a felony, making him or her unfit to handle and use firearms; (ii) that the person has sufficient experience using firearms; (iii) that the person must possess the required level of knowledge pertaining to the legal concepts of self-defence and necessity; ${ }^{83}$ and finally, (iv) that personal circumstances may not make the approval alarming. Regarding the criminal record assessment, eligibili-

81. Guidelines for Navigation Waters with a Piracy Threat, Including the Use of Private Armed Guards, No. 3/2014. Available at: https:// www.danishshipping.dk/politik/pirateri/ (last visited 1 February 2019).

82. ACG Ordinance, Art. 7, nos. 1-6.

83. Criteria further discussed in Section 3 ty is not equal to zero tolerance. According to the preparatory work, any conviction for offences inflicting 'longer imprisonments', because of homicide, manslaughter, arson and rape shall automatically be disqualifying. Minor offences, unless following from the Weapons Act, are not disqualifying per se. A colourful example is provided in the preparatory work. 'If a person by mistake brings an otherwise illegal knife to public areas, because he or she has used it legally for fishing an forgot to store it properly, the person is not automatically disqualified.' Likewise, in the case of 'bar fights the underlying circumstances shall be taken into consideration' ${ }^{84}$ The complexity of such an assessment makes it controversial to leave it with a ship owner or potentially a foreign PSC, especially because it induces an overlap between the entitled and entrusted party. Experience with firearms is considered fulfilled if the person can demonstrate at least two years of police or military employment. ${ }^{85}$ In this case it is not a factual requirement that experience is gained form Danish services, and in most cases the guards are of foreign nationality. In relation to the applicant's personal circumstances, the person should be deemed unfit, if he or she, appears to be mentally or physically unable to function as a guard. Surprisingly, the ordinance is silent when it comes to how this kind of information should be obtained in the first place. Consequently, the likelihood that such information will come to the ship owner's attention is questionable, meaning that the PSCs' willingness to abide by the law and adopt high standards is pivotal to secure the quality of PCASP teams.

When conducting a side-by-side examination of Article 7 and recommendations articulated in the IMO guideline and ISO standard, respectively, it becomes apparent that both instruments impose higher standards than Danish law. To name a few examples, the IMO guideline specifies that all guards shall receive a minimum shipboard familiarisation training, demonstrate knowledge of the ISPS and ISM codes and undertake medical training. ${ }^{86}$ The ISO standard consist of four pages divided into the following topics: training and communication, with detailed instructions on qualifications. ${ }^{87}$ When it comes to the actual number of guards to be deployed, the ordinance is also silent. According to general recommendations, a PCASP team should be no less than four persons. ${ }^{88}$ This allows the team to work in pairs and in shifts. It would also mean that the team can cover all angles on the ships and thereby eliminate blind spots. Consequently, it is fair to conclude that the recommendations set forth in IMO guidelines and international standards are well over the threshold of Danish law. But since neither the IMO guideline nor the ISO

84. Preparatory work (L 116 2011-2012) 15; I.B. Møberg and C.A. Gulisano, Civile, bevæbnede vagter på danske lastskibe, Juristen nr. 4 (2012) 208.

85. Preparatory work (L 116 2011-2012), at 15 (author's underlining and interpretation).

86. MSC.1/Circ.1405/Rev. 2, Annex, at 4.

87. ISO 28007, at 12-16.

88. Guardcon, Part II, cl. 3. 


\begin{tabular}{lll}
\hline Assignments & Individual license & General license \\
\hline Competence to issue a license & Ministry of Justice & Ministry of Justice \\
\hline $\begin{array}{l}\text { Approve procedures include ship protection meas- } \\
\text { ures }\end{array}$ & $\begin{array}{l}\text { Private classification societies on } \\
\text { behalf of the Maritime Authority }\end{array}$ & $\begin{array}{l}\text { Private classification societies on } \\
\text { behalf of the Maritime Authority }\end{array}$ \\
\hline Approve routing & Ministry of Defence & Ship owners \\
\hline $\begin{array}{l}\text { Approve weapons, including types and ammuni- } \\
\text { tion }\end{array}$ & Ministry of Justice & $\begin{array}{l}\text { Ship owners within the ambit of the } \\
\text { ordinance }\end{array}$ \\
\hline Competence to vet the guards & Ministry of Justice & Ship owners or PSCs
\end{tabular}

Table 1 compiled by author.

standard is considered mandatory in regard to the ACG Ordinance it is ultimately entrusted to private actors to ensure the guard's quality.

\subsection{Evaluation}

The previous sections contain an examination of the requirements to obtain an authorisation applicable under Danish law. It entails two different licensing schemes, which is vastly different in form and content. The key issues discussed previously are competence to issue a license, formulation of procedure for precautionary measures, approval of routing, weapons, and especially the competence to vet the guards, as summarised in Table 1.

The column to the left entails the assignments that must be observed during the authorisation process. As shown, the individual license is subject to strict state control, whereas the tasks are delegated to private actors according to the general license. Consequently, the main differences in terms of the individual and general licensing schemes is two-fold. First, the purpose of the general license is to untie the link between the individual guards and the weapons certificates. Instead, the permit is issued to the ship owner, which makes it less complicated to embark and disembark weapons and guards. Second, the general license is subject to a high degree of delegation of authority, which is untraditional from a Danish legal perspective. Thus, the industry-friendly authorisation scheme demonstrates a minimum of state involvement when it comes to gun regulation and control of private security providers.

\section{The Use of Force in Self- defence}

Up until this point, the analysis has focused on the authorisation, broadly speaking what is required before a PCASP team can legally embark on a Danish-flagged ship. From this point on, the scenery changes to the situation on board the ship at sea and the guard's potential use of force in self-defence. This perspective is only subject to limited political consideration, despite being at the absolute centre of attention in the international debate. ${ }^{89}$ No focus has been allocated to discussing the concept of 'monopoly of force', indicating that the government's perception of the act is merely use of force exercised by private actors in some form of 'improved' self-defence.

The problems of using private actors to protect commercial ships against piracy are crystallised in three ways. First, it is a question of using firearms without inflicting unlawful harm to attackers and thereby risking criminal liability. Second, the chain of command between the ship's master and the PCASP team has turned out to be complicated as a potential dichotomy between the master's competence as the highest authority on the ship and the individual right to self-defence may collide. Especially if the master believes the safety of the ship is at risk, ${ }^{90}$ it raises the question of whether the master has the authority, or even an obligation, to order ceasefire. Legal issues can also materialise in the form of complicity, as it is generally recommended that the team leader consult the master when suspicious activity is detected. Nevertheless, the master should exercise caution in giving instructions to the team leader, as it could be perceived as incitement for which criminal liability can be imposed. ${ }^{91}$ Third, in the wake of an attack the master must take certain post-incident obligations into consideration.

\subsection{Legal framework}

International law does not provide an answer to the question of use of force in self-defence for private actors at sea. The legal framework for use of force by states
89. Dutton, above n. 71.

90. SOLAS Convention, chapter $\mathrm{XI}-2$, regulation 8 .

91. Penal Code Art. 21 '(1) Acts aimed at inciting or assisting the commission of an offence are punishable as attempts if the offence is not completed. (2) The penalty prescribed for an offence may be reduced for attempts, especially where an attempt reflects little strength or persistence of criminal intent. (3) Unless otherwise provided, attempts will only be punished if the offence is punishable by imprisonment for a term exceeding four months.' 
cannot be adopted for PCASP teams. ${ }^{92}$ Instead, the main source to consult is the law of the flag State. ${ }^{93}$

In relation to a legal basis, the preparatory work is silent. ${ }^{94}$ This is presumably because the authority to the use of force in self-defence does not differ from the situation according to an individual license, meaning the continuous application of the Penal Code as the normative framework. This assumption is also supported by the ACG Ordinance's Article 7(5) which stipulates that all guards must possess a minimum level of knowledge on self-defence (nødværge) and emergency law (nødret). As it is the ship owner or the contracting PSC who must ensure the eligibility of the individual guard, criminal liability will fall to either party should the requirements not be met; however, the individual guard must be answerable for his or her actions. In summary, the use of force shall be evaluated on the basis of the generic rule on self-defence in the Penal Code. ${ }^{95}$ From a theoretical standpoint, it is less problematic to apply the same rule for actions following from a pirate attack or an 'ordinary' attack in society. But the controversial and disputable fact is the lack of substantive rules on how to operationalise concepts such as proportionality and necessity in practice. Especially, as the risk of using weapons is relatively high, given the fact that PCASP teams should only be deployed in piracy-prone waters. In addition, the likelihood of causing personal injuries or fatal harm in the case of shooting is apparent. Such kind of improved self-defence by allowing guns is otherwise reserved for state agents, such as police officers and military staff. Apart from the obvious difference between services of state agents and PCASP teams, respectively, the former group is officially mandated. Likewise, such personnel's actions are clarified with the help of administratively formulated guidance in the form of the so-called use-of-force barometer drafted by public authorities. ${ }^{96}$

To mend the lacunas, various ISR guidelines and, to a certain degree the IMO, have addressed the subject matter. The most pronounced examples are BIMCO's guidance on the use of force ${ }^{97}$ and the ' 100 Series Rules'

92. D. Guilfoyle, 'The Use of Force against Pirates', The Oxford Handbook of the Use of Force in International Law (2015); B. Feldtmann, 'Må man skyde en pirat - Et indblik I den retlige ramme for statslige aktørers magtanvendelse', Fetsskrift til Nis Jul Clausen (2013) 130.

93. Petrig, above n. 12, 689

94. K. Østergaard and M.L. Holle, 'Pirateri - anvendelse af civile bevæbnede vagter om bord på danskflagede lastskibe', Juristen (6) (2012) 292.

95. Danish Penal Code, Art. 13(1) 'Acts committed in self-defence are exempt from punishment if they were necessary to resist or ward off a present or imminent wrongful assault and do not manifestly exceed the limits of what is reasonable in view of the danger from the assault, the assailant himself and the importance of the interest assaulted. (2) Any person who exceeds the limits of lawful self-defence will be exempt from punishment if the irregular act could reasonably be attributed to the fear or excitement produced by the assault.'

96. I. Henricson, Politiret (2016) 271

97. BIMCO Guidance on Rules for the Use of Force (RUF) by Privately Contracted Armed Security Personnel (PCASP) in Defence of a Merchant Vessel (MV; hereinafter BIMCO RUF). Can be obtained on BIMCO's webpage https://www.bimco.org/ (last visited 1 February 2019). commonly dubbed RUF. ${ }^{98}$ The former guideline is adopted by BIMCO as a supplement to the standard contract Guardcon, and the latter is drafted by an English lawyer, both taking a starting point in English law. For obvious reasons, it is plausible for private actors to resort to existing instruments rather than drafting their own set of guidelines. The drawback however is the likely risk that 'one size does not fit all.' Although the right to self-defence, as a legal norm negating criminal liability, is considered as an almost universal principle, the concrete objective and content of the rule may vary among states. ${ }^{99}$ The same can be argued with regards to the mental requirement of mens rea. To pinpoint a practical example, some jurisdictions detail a duty to retreat before using force. ${ }^{100}$ Simply to rely on recommendations is therefore not only controversial but is also likely in conflict with the principles of legality and lex certa. In addition, it is not convincing to base a justification on the line of argumentation that actions simply comply to international soft laws or ISR instruments, which also jeopardises the guard's legal position. Notwithstanding, the lack of alternatives in the ambit of these guidelines must be examined.

According to the guidelines, the deterrence act can be divided into an escalation phase and a de-escalation phase, respectively, providing a graduated approach. This is to ensure that guns are not used before the attack is initiated or after it is fended off. When evaluating the guidelines, it becomes evident that the escalation phase is more nuanced and accordingly easier to operationalise in practice. As a first and second step, the team leader, shall advise the master, that he intends to invoke the rules, allowing the guards to use non-kinetic warnings. ${ }^{101}$ Such actions will in casu not quality as use of force. Second, the guards can resort to firing warning shots if the attackers fail to react. In case they continue to approach the ship, it indicates that a pirate attack is most likely in effect. Consequently, lethal force can be used, but only as a last resort. This also means if less harm can be exercised by firing at the skiff's engine or non-vital parts of the body, the guards shall choose to cause a lesser degree of personal harm. In contrast to the escalation phase, the de-escalation phase can be more difficult in practice, as successive or prolonged use of force is not allowed. It raises the question of how to determine whether the pirates have withdrawn from the attack. The guidelines do not provide much guidance on this end of the spectrum but simply refer to the overarching principles of proportionality and necessity. ${ }^{102}$

98. The 100 Series Rules: An International Model Set for Maritime Rules for the Use of Force, can be obtained by a simple search on the Internet (hereinafter 100 series).

99. Petrig, above n. 12, 668

100. U. Sieber and C. Kornils, 5 Nationales Strafrecht in rechtsverg/eichender Darstellung, (2010)

101. 100 Series Rule 1 and Rule 2. BIMCO RUF is divided into different weapon stages: normal, heightened and stand to. It also contains different types of firing, e.g. warning shots, disabling fire, deliberate direct fire and, finally, use of lethal force, 4-5.

102. 100 Series Rule, 2; BIMCO RUF, 2. 


\subsection{Chain of Command}

The previous section addressed the question of use of force in self-defence as it was to be performed in a physical vacuum, with no interference from other parties than the attackers (pirates) and the defenders (guards). This is of course in stark contrast to reality and the situation on ships which are isolated at sea. This circumstance has given rise to concerns regarding authority and chain of command. The reason for this potential conflict is the possible clash between the master's position as the highest authority on the ship as reflected in international as well as national laws, and the guard's individual right to act in self-defence and in defence of others. From the perspective of the master, the question is basically to what degree he or she can maintain full authority without being held criminally liable for the actions of others. From the guard's perceptive the question can be summarised to whether they shall obey the master, should he or she give instructions that a continuous use of force is either considered unlawful or is likely to bring the ship in distress at sea.

The starting point is that special competences are bestowed on the master compared to most other private employment relationships, as stipulated in the Seaman's Act. ${ }^{103}$ Once considered as 'master under God', the rhetorical statement illustrates the almost unlimited powers bestowed on the master to act on behalf of the ship owner and instruct crew and passengers. The authority of the master to act on behalf of the ship owner has been downgraded during the past century, due to the development of electronic communication. ${ }^{104} \mathrm{Nev}$ ertheless, when it comes to the daily operation, navigation and situations of peril to which actions without hesitation are required, the master is undoubtedly in charge.

The interplay between the master and PCASP team has not been debated by the parliament; however, the issue is addressed in international law and various other legal instruments. The narrative of most instruments is that nothing shall be construed as a derogation of the master's authority. Instruments such as the 100 Series and BIMCO RUF seek to mitigate the dichotomy by means of communication. According to the guidelines, the team leader shall not only advise the master in case of an imminent threat but also inform the master that the RUF is about to be invoked, meaning that the PCASP team will step in front, and the team leader will be responsible for all decisions in such a situation, except for the master's right to order a ceasefire. ${ }^{105}$ From a criminal law perspective, this seems questionable, as the right to self-defence cannot be confined by agreement, and the individual guard's right to self-defence it not confined by lex specials, meaning the argumentation becomes circular.

103. The Seaman's Act (LBK no. 73; 17 January 2014), para. 51

104. E.V. Hooydonk, 'The Law of Unmanned Merchant Shipping - An Exploration', JIML 412 (2012).

105. BIMCO Guidance on Rules for the Use of Force (RUF) by Privately Contracted Armed Security Personnel (PCASP) in Defence of a Merchant Vessel (MV), at 3

\subsection{Post-incident Obligations}

Surprisingly little attention has been directed to postincident obligations. This section will not present a detailed analysis but merely provide an overview of the problems arising after a pirate attack has been repelled.

The ACG Ordinance stipulates a reporting obligation in the case of use of force. It is laid down in Article 8, which consists of four subparagraphs. The starting point is that the responsible ship owner must report any use of force in writing within seventy-two hours of the incident. A report shall include a description of the incident, including the persons involved and the intensity of the use of force. ${ }^{106}$ In case audio and video recordings are available, this should be included in the report. ${ }^{107}$ If, however, there is reason to believe that the actions have caused personal injury or death, reporting shall be given immediately to the police. ${ }^{108}$ Special obligations are also listed in the Antipiracy Ordinance. According to section 6 , subparagraph 1 , no. 6 , the previously discussed procedures must entail recommendations to the master on reporting to other ships in the area in case of a pirate attack. The master is to inform and alert other ships, whereas the obligation according to the ACG Ordinance is to ensure that law enforcement measure can be taken if necessary. ${ }^{109}$

Apart from the two special rules, both international laws and national laws impose general obligations on the master. One relevant issue is the obligation to render assistance for persons at distress at sea as formulated in the SOLAS convention chapter $\mathrm{V}$, regulation 33.1. It states that the

The master of a ship at sea which is in a position to be able to provide assistance (...), is bound to proceed with all speed to their assistance (...). The duty to assist must always be evaluated in regard to the safety of the ship and persons on board. ${ }^{110}$

Another delicate issue is the master's duty to investigate potential offences and if necessary take further actions to detain the parties. ${ }^{111}$ It means in theory that the master, if possible, must evaluate the actions of the guards. This is for obvious reasons a rather controversial, however necessary, obligation.

\section{Concluding Remarks and Outlook}

At the time of writing, roughly hundred Danish-controlled ships are navigating in piracy-prone areas at any

\footnotetext{
106. Art. 8, subpara. 2.

107. Art. 8, subpara. 4

108. Art. 8, subpara. 3

109. Bill proposal L 116 (2011-2012) 15-16.

110. See further discussions on the topic in B. Feldtmann, 'What Happens after the Defense: Considering Post-Incident Obligations of Masters from the Perspective of International and Danish Law', ODIL (2015).

111. The Seaman's Act, Section 63.
} 
given time. ${ }^{112}$ Accordingly, most ship owners employing Danish-flagged ships in one of these areas are expected to hold a general license for the potential use of PCASP teams. Since the LEOPARD incident in 2011 no successful hijackings have been recorded against Danish ships, albeit TORM announced two pirate attacks in 2013 and 2014, respectively. ${ }^{113}$ Unlike the hijacking incidents, both of TORM's ships were equipped with armed guards that repelled the attacks, without inflicting personal injuries to the crew or the pirates. Hence, the use of armed guards is generally considered successful.

Surprisingly little attention has been devoted to discussing the topic in the political and national scholarly debate. On that backdrop of the analysis it is fair to argue that the Danish model of regulation holds a high privatisation factor. Not only are PCASP teams the preferred solution over VPD teams, but the intensity of delegation of authority to private actors is also unique. This is evident by comparing with equivalent areas of Danish law and the current state of law in other flag States. Furthermore, it is demonstrated throughout this article that the Danish form of regulation to some extent relies on soft law and industry self-regulation, which serve as guidance, without automatically obtaining the status of formal law. In summary, Danish lawmakers have chosen to regulate this complex area of law, traditionally subject to strict rules within the characteristic regulatory framework of maritime law. As noted in the introduction, the legal framework corresponds with the legal policy concerns articulated by the parliament. Nevertheless, as the nature of shipping hampers state control and oversight mechanics, the Danish form of regulation is not prone to criticism. Especially the fact that it is the ship-owning company or the contracting private security company that undertakes the selection and vetting of the guards is disputable. Consequently, the decision-making powers of the beneficiary party and competent party are overlapping. In the case of the guard's use of force in self-defence and the question pertaining to the mater's authority, the lack of lex specialis leaves the involved parties in a grey zone. Fortunately, no serious incidents have occurred so far, but one could be fearful of skeletons in the closet, should harm come to attackers or defenders.

Looking back in time, Danish lawmakers acted on the request of the shipping industry and adopted new regulations which accommodate the call for more flexibility. This is largely praised by industry stakeholders, opposed to the scepticism voiced by scholars. As the subject matter is not currently on the political agenda, no ambition to amend the current state of law has been expressed. In summary, the Danish form of regulation can be described as commercially convenient but doctrinally dubious. ${ }^{114}$ 